\title{
Analisis Pengaruh Stock Split Terhadap Harga Saham, Abnormal Return Dan Risiko Sistematik Saham Perusahaan (Studi Pada Perusahaan Yang Terdaftar Di Bei 2016-2018)
}

\author{
Nindi Vaulia Puspita1 \& Kartika Yuliari² \\ Universitas Kadiri - Kediri \\ E-mail : nindi.vaulia@unik-kediri.ac.id ${ }^{1}$ \\ kartikay@unik-kediri.ac.id²
}

\begin{abstract}
The purpose of this study is to analyze the effect of stock split on stock price, abnormal return and systematic risk of stock, The sample in this study as many as 82 companies are doing stock splits in the period 2016-2018 with the requirement that no other corporate actions such as mergers and acquisitions or reverse stock splits. The result indicated there are differences in stock prices and abnormal return before and after the stock split event, and the systematic risk no difference after and before the stock split event. This condition because of the strong internal factors of the company, this is indicated by no effect of systematic risk (beta) on stocks due to unstable market because investors buy stocks in the short term so they are not affected by systematic risk.
\end{abstract}

Key words: stock split, stock price, Abnormal Return, systematic risk

\begin{abstract}
ABSTRAK
Penelitian bertujuan untuk melakukan analisis pengaruh stock split terhadap harga saham, abnormal return dan risiko sistematik saham, sampel penelitian terdiri dari 82 perusahaan yang melakukan stock split dalam rentang waktu 2016-2018 dengan persyaratan tidak ada corporate action yang lain seperti merger dan akuisisi ataupun reverse stock split. Hasil penelitian menunjukkan terdapat perbedaan harga saham sebelum dan sesudah peristiwa stock split, adanya perbedaan abnormal return sebelum dan sesudah stock split dan yang terakhir risiko sistematik menghasilkan tidak adanya perbedaan setelah dan sebelum adanya peristiwa stock split, kondisi ini karena kuatnya factor internal perusahaan, hal ini ditunjukkan dengan tidak adanya pengaruh risiko sistematik (beta) terhadap saham yang disebabkan kondisi pasar yang tidak stabil menyebabkan investor membeli saham dengan tujuan jangka pendek sehingga tidak terpengaruh dengan risiko sistematik.
\end{abstract}

Kata Kunci: stock split, harga saham, Abnormal Return, risiko sistematik

\section{PENDAHULUAN}

Dewasa ini pasar modal Indonesia mengalami perkembangan yang cukup signifikan, dimana menurut PT Kustodian Efek Indonesia (KSEI) pada akhir desember 2018 pasar modal mengalami kenaikan signifikan sebesar 44\% dibandingkan tahun 2017 , 
dimana tercatat single investor identification (SID) sebesar 1,1 juta di tahun 2017 dan meningkat menjadi 1,6 juta di tahun 2018 .

Menurut Tandelilin (2010) pasar modal memiliki fungsi lembaga perantara, yaitu pasar modal berperan dalam menghubungkan pihak yang membutuhkan dana (emiten) dengan pihak yang kelebihan dana (investor).

Dalam melakukan investasi, investor selalu memperhitungkan antara besrnya risiko dan juga return yang diterimanya dalam setiap investasi sahamnya. Dimana investor selalu bertindak dapat memperoleh return yang maksimal dan meminimalkan risiko yang akan ditanggung. Menurut Prastiono (2012) yang memberikan pengaruh pada penawaran dan permintaan saham adalah harga saham. Dimana saat harga saham mengalami keinaikan maka daya beli investor akan berkurang yang menyebabkan jumlah permintaan saham juga berkurang, begitu pula kondisi sebaliknya.

Corporation action yang sering dilakukan oleh emiten atau perusahaan untuk mencapai tingkat keseimbangan pasar saham adalah melakukan stock split (stock split). Stock split menurut Halim (2005) adalah tindakan perusahaan untuk melakukan pemecahan jumlah satu lembar saham menjadi lebih banyak dengan nilai nominal yang lebih rendah perlembar sahamnya, dengan tujuan agar harga saham di pasar tidak terlalu tinggi sehingga saham emiten lebih banyak diperdagangkan.

Kent et al (2012) menyatakan motivasi perusahaan melakukan stock split adalah menurunkan harga dan meningkatkan liquiditas saham emiten. Keberagaman jenis biaya keuangan berbeda untuk setiap perusahaan (Putra \& Yuliari, 2017). Sehingga dapat memberikan sinyal kepada masyarakat bahwa perusahaan memiliki prospek yang baik dalam bidang pemberian return dimasa yang akan datang.

Efek stock split terhadap keuntungan yang didapat oleh investor juga dijelaskan oleh Grinblatt, et al (2014) yang menunjukkan bahwa pengumuman adanya stock split pada perusahaan akan membentuk harga saham yang abnormal, dimana setelah stock split return yang didapatkan akan meningkat sehingga menarik investor untuk melakukan investasi dan dengan banyaknya investor yang ikut berpartisipasi dalam aksi jual atau beli setelah stock split memberikan efek harga saham stock split akan meningkat.

Abnormal return dijadikan sebagai alat analisis yang digunakan dalam sebuah studi peristiwa stock split, karena setelah peristiwa stock split maka memunculkan abnormal 
return karena flutuasi harga saham. Abnormal return adalah kelebihan dari return sesungguhnya yang terjadi terhadap return yang normal (Jogiyanto,2010)

Stock split bukan elemen yang akan meningkatkan harga saham emiten, melainkan menurunkan harga sekuritas yang memberikan dorongan investor untuk melakukan investasi yang dapat meningkatkan laba dan deviden kas. Bertambahnya jumlah pemegang saham disebabkan oleh penurunan harga dan votalitas yang menghasilkan ketertarikan investor untuk memperbanyak jumlah saham yang dipegang (Jogiyanto, 2010).

Joshi (2014) melakukan penelitian tentang pengaruh stock split terhdap return dan likuiditas menemukan adanya reaksi yang positif dari pasar dengan naiknya abnormal retun setelah munculnya pengumuman stock split. Kurniawati (2013) dalam penelitiannya menunjukkan adanya sinyal positif begitu diumumkan informasi stock split kepada publik oleh pihak manajemen.

Risiko sering dihubungkan dengan penyimpangan atau deviasi dari outcome yang diterima dengan yang diekpektasikan (jogiyanto,2012). Investasi yang efisien adalah investasi yang memberikan risiko minimal dengan tingkat keuntungan yang maksimal (widianingsih,2016). Aktivitas stock split memberikan efek berubahnya jumlah saham yang beredar, sehingga investor diharuskan kembali melakukan penyusunan kegiatan invesatsinya dengan memperhitungkan jumlah risiko yang harus ditanggung (khusfatun,2011).

Stock split adalah sebuah fenomena yang hingga saat ini masih sering menjadi tekateki bagi bidang ekonomi, hal ini karena banyaknya ketidakcocokan antara teori dan praktik. Namun beberapa bukti empiris menunjukkan adanya reaksi pasar terhadap pengumuman stock split, dengan adanya fenomena peristiwa stock split, maka diambilah penelitian “Analisis Pengaruh Stock Split Terhadap Harga Saham, Abnormal Return Dan Risiko Sistematik Saham Perusahaan (Studi Pada Perusahaan Yang Terdaftar Di Bei 2016-2018)"

\section{Rumusan Masalah}

1. Apakah ada pengaruh pada harga saham sebelum dan sesudah emiten melakukan aksi stock split? 
2. Apakah ada pengaruh pada abnormal return sebelum dan sesudah emiten melakukan aksi stock split?

3. Apakah ada pengaruh terhadap risiko saham sebelum dan sesudah emiten melakukan aksi stock split?

\section{Tujuan Penelitian}

Mengetahui pengaruh harga saham, abnormal return dan risiko saham sebelum dan sesudah dilaksanakan stock split oleh emiten

\section{KAJIAN PUSTAKA}

\section{Pasar Modal}

Tandelilin (2010) menyatakan pasar modal adalah tempat bertemunya antara pihak yang memiliki kelebihan dana dengan pihak yang membutuhkan dana dengan cara memperjual belikan sekuritas dalam bentuk surat berharga. Menurut Indonesian stock exchange (BEI) pengertian pasar modal (capital market) adalah pasar untuk berbagai instrumen keuangan jangka panjang yang bisa diperjualbelikan baik surat utang (obligasi), ekuiti (saham), reksa dana, instrumen derivatif maupun instrumen keuangan lainnya (www.idx.co.id).

Kegiatan di pasar modal adalah membeli instrument keuangan yang diperdagangkan di pasar modal dengan harapan memperoleh return di masa yang akan datang (Sjahrial, 2009). Peran pasar modal sangat berpengaruh bagi perekonomian suatu negara karena pasar modal menjalankan dua fungsi sekaligus yaitu fungsi ekonomi dan fungsi keuangan (Copeland,2010). Fungsi ekonomi pasar modal yakni berfungsi sebagai lembaga perantara (intermediaries) penghubung antara pihak yang berkelbihan dana dengan pihak yang kekuarangan dana sesuai dengan karekteristik investasi yang dipilih (Birgham,2013).

\section{Saham}

Fahmi (2014) menyatakan bahwa saham adalah: (a) Tanda bukti penyertaan kepemilikan modal/dana pada suatu perusahaan; (b) Kertas yang tercantum dengan jelas nilai nominal, nama perusahaan dan diikuti dengan hak dan kewajiban yang dijelaskan kepada setiap pemegangnya; (c) Persediaan yang siap untuk dijual. Menurut tandelilin (2010) saham dibagi menjadi: 
a. Saham biasa adalah surat yang menunjukkan bukti kepemilikan terhadap suatu perusahaan, dimana investor yang menyertakan modalnya dalam bentuk saham akan memperoleh balas jasa berupa dividen. Pemegang saham biasa memiliki hak suara pada rapat umum pemegang saham (RUPS). Hak suara ini bersifat proposional sesuai dengan jumlah lembar saham yang dimiliki.

b. Saham preferen (preferen stock) memiliki kesamaan dengan saham biasa yaitu samasama menunjukkan kepemilikan suatu perusahaan melalui penyertaan modal. Saham preferen memiliki sifat gabungan antara saham biasa dan obligasi, dimana pemilik saham preferen menerima balas jasa berupa dividen yang bersifat tetap.

c. Saham treasuri (treasury stock) adalah saham milik perusahaan yang pernah dikeluarkan dan beredar yang kemudian dibeli kembali oleh perusahaan untuk tidak dipensiunkan tetapi disimpan sebagai saham treasuri.

Saham preferen dan saham treasuri tidak begitu populer di Indonesia maka istilah saham yang pada umumnya sering digunakan oleh investor biasanya mengacu pada saham biasa.

\section{Harga Saham}

Menurut Sutrisno (2009) pengertian harga saham adalah nilai saham yang terjadi akibat diperjual-belikan saham di pasar sekunder. Tandelilin (2010) menyatakan bahwa harga saham merupakan cerminan dari ekspektasi investor terhadap faktor-faktor earning, aliran kas, dan tingkat return yang disyaratkan investor, yang mana ketiga faktor tersebut juga sangat dipengaruhi oleh kondisi ekonomi makro suatu negara serta kondisi ekonomi global. Brigham (2010) menyatakan faktor yang mempengaruhi fluktuasi harga saham yaitu:

\section{1) Faktor Internal}

Faktor internal terdiri dari pengumuman tentang pemasaran, produksi dan penjualan, pengumuman pengambil alihan diversifikasi, pengumuman investasi, pengumuman pendanaan,pengumuman badan direksi manajemen, pengumuman ketenagakerjaan, dan pengumuman laporan keuangan perusahaan

2) Faktor Ekternal

Faktor eksternal pergerakan harga saham adalah sebab-sebab perubahan harga saham yang berasal dari luar perusahaan. Faktor-faktor yang termasuk kedalam faktor eksternal pergerakan harga saham yaitu Pengumuman dari pemerintah, Pengumuman 
hukum, Pengumuman industri sekuritas, Gejolak politik, Fluktuasi nilai tukar dan isu-isu dari dalam dan luar negeri.

Dahat (2012) menyatakan secara teori, stock split tidak menciptakan nilai ekonomi tetapi dalam praktek pasar meberikan sinyal positif terhadap informasi stock split yang dilakukan perusahaan. Kondisi ini disebabkan karena Stock split memberikan sinyal yang positif dalam bentuk informasi mengenai kinerja perusahaan yang bagus kepada investor, selain ituu stock split juga dapat meningkatkan likuiditas perdagangan saham karena setelah stock split harga saham dapat lebih dijangkau oleh investor

\section{Abnormal Return}

Jogiyanto (2010) menyatakan abnormal return adalah kelebihan dari imbal hasil yang sesungguhnya terjadi (actual return) terhadap imbal hasil normal. Imbal hasil normal merupakan imbal hasil ekspektasi (expected return) atau imbal hasil yang diharapkan oleh investor.

Dengan munculnya fenomena informasi stock split, abnormal return yang positif setelah stock split dapat memberikan keuntungan di atas normal pada investor, dan sebaliknya bila abnormal return setelah stock split negatif menunjukan bahwa tingkat keuntungan yang di dapat investor di bawah normal (Pramana, 2012). Abnormal return seringkali dijadikan sebagai focus dalam pengamatan reaksi harga atau efisiensi pasar. Karena return yang dihasilkan adalah return yang melebihi dari ekpektasi (birgham,2012)

\section{Risiko Sistematik Saham}

Risiko sistematik adalah hubungan antara suatu pengembalian portofolio dan pengembalian pasar yang berbeda (keown,2011). Sedangkan menurut tjiptono (2006) beta merupakan ukuran angka koefisien yang menggambarkan sensivitas atau kecendrungan respons suatu saham terhadap pasar. Saham dengan beta satu merupakan saham yang bergerak searah dengan pergerakan pasar, sedangkan saham dengan beta kurang dari satu merupakan saham yang bergerak lebih lambat dari pergerakan pasar, dan yang terakhir saham dengan beta lebih dari satu menggambarkan harga saham bergerak lebih fluktuatif disbanding dengan pasar, maka dapat diketahui bahwa Beta merupakan suatu tolok ukur atau ukuran untuk menghitung Risiko Sistematik, hal ini dikarenakan Beta menunjukkan adanya hubungan antara return saham dengan return pasar 


\section{Stock Split}

Menurut Pramana (2012) "stock split adalah pemecahan sejumlah saham yang beredar dari suatu perusahaan tanpa pembebanan apapun dalam ekuitas pemegang saham“. Brigham (2011) menjelaskan Stock Split adalah tindakan yang diambil oleh perusahaan untuk meningkatkan jumlah lembar saham beredar, seperti memberikan dua saham baru dari satu lembar saham yang dimiliki oleh investor (Birgham,2011)

Stock split prinsipnya tidak mempengaruhi modal disetor penuh, yang mengalami perubahan adalah nilai nominalnya setelah stock split menjadi lebih kecil dengan jumlah lembar saham baru yang beredar lebih banyak (Hadi, 2013). Tujuan perusahaan melakukan aksi stock split adalah sebagai berikut Fahmi (2013) :

a) menghindari harga saham yang terlalu tinggi karena memberatkan masayarakat untuk membelinya

b) Mempertahankan tingkat likuiditas saham

c) Menarik investor baru untuk memiliki saham tersebut

\section{Kerangka Konseptual}

a. Pengaruh stock split terhadap harga saham

Berdasarkan beberapa teori, aksi stock split seharusnya tidak menciptakan nilai ekonomi namun kondisi nyatanya pasar bereaksi positif terhadap informasi stock split yang dilakukan perusahaan. Efek dari pengumuman stock split adalah efek likuiditas dari harga saham karena dengan adanya stock split harga saham yang semula bernominal tinggi dapat lebih mudah diperdagangkan karena nominalnya menjadi lebih rendah. Prasetyo (2015) meneliti tentang efek Stock split terhadap Harga Saham pada Perusahaan Go Public di Bursa Efek Indonesia 2011 - 2014 dengan menggunakan alat ukur Wilcoxon Signed Rank Test menunjukkan hasil bahwa ada perbedaan harga saham sebelum dan sesudah stock split.

b. Pengaruh stock split terhadap abnormal return.

Signaling theory menjelaaskan bahwa dengan fenomena pengumuman stock split dapat dianggap sebagai sinyal positif dari manajemen tentang prospek perusahaan dimasa yang akan datang. Aksi perusahaan dalam kegiatan stock split menunjukkan kondisi perusahaan yang bagus sehingga akan memberikan keuntungan pada investor dimasa yang akan datang. 
Kurniawati (2003) menemukan reaksi yang signifikan dari pengumuman stock split terhadap abnormal return. Hal ini berkaitan dengan stock split sebagai sinyal yang positif karena manajer perusahaan akan menyampaikan prospek perusahaan di masa depan yang bagus.

c. Pengaruh stock spilt terhadap risiko sistematik saham

Perilaku investor dalam menghadapi risiko selalu berbeda, dimana hal ini dicerminkan melalui reaksi pasar. Reaksi pasar terhadap stock split sebenarnya bukanlah terhadap tindakan kegiatan stock split, melainkan terhadap prospek perusahaan di masa yang akan datang melalui kegiatan stock split (Azizan, 2012). Menurut penelitian khusfatun (2014) menyatakan bahwa kegiatan reverse split ataupun stock split memberikan pengaruh terhadap risiko sistematik $(\beta)$ ssaham, dikarenakan para invetor dituntut untuk menysun kembali investasi yang dimilikinya. Berdasarkan uraian kerangka konseptual, maka digambarkanlah kerangka konseptual sebagai berikut:

\section{Gambar 1 : Kerangka Penelitian}

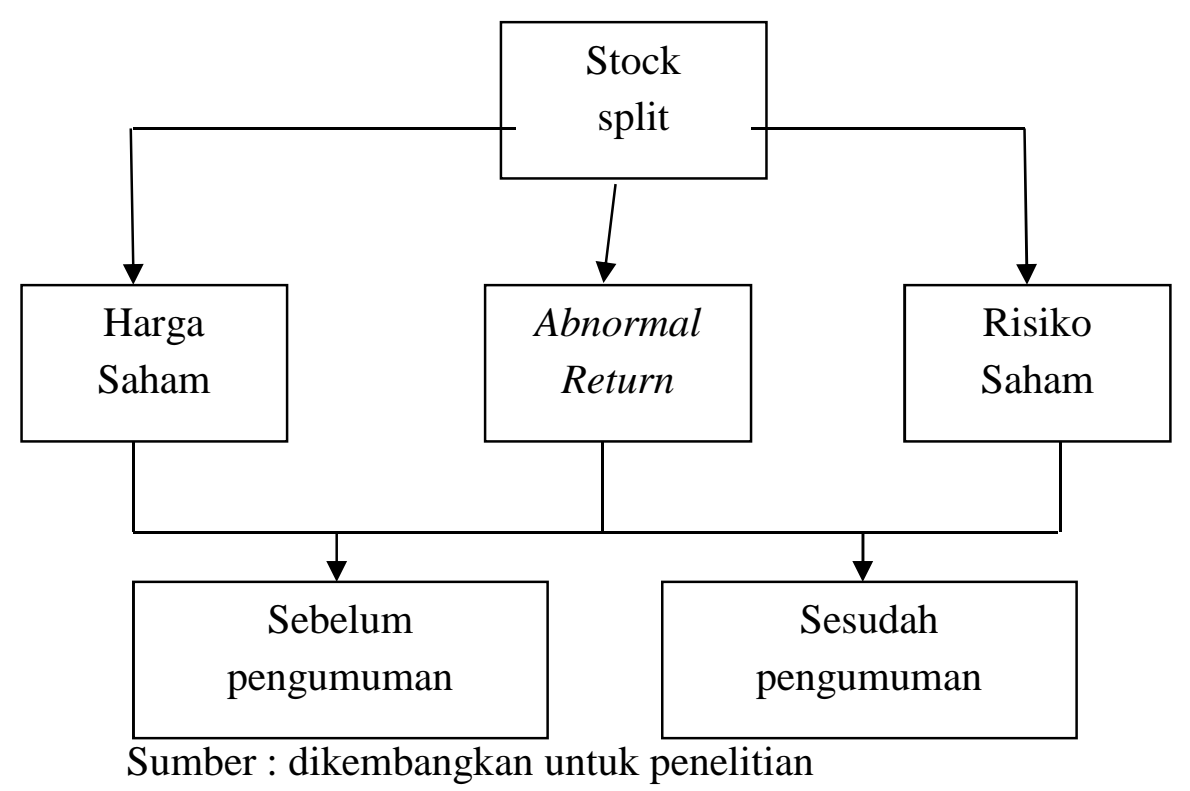

Hipotesis yang digunakan dalam penelitian ini adalah:

H1 : stock split diduga memberikan pengaruh terhadap harga saham dalam periode sebelum dan setelah pelaksanaan pengumuman

$\mathrm{H} 2$ : stock split diduga memberikan pengaruh terhadap abnormal retun dalam periode sebelum dan setelah pelaksanaan pengumuman 
H3 : stock split diduga memberikan pengaruh terhadap risiko saham dalam periode sebelum dan setelah pelaksanaan pengumuman

\section{METODE PENELITIAN}

\section{Jenis Penelitian}

Jenis penelitian yang digunakan adalah studi peristiwa (event study). Hartono (2010) menjelaskan bahwa penelitian studi peristiwa (event study) adalah "studi yang mempelajari reaksi pasar terhadap suatu peristiwa yang informasinya dipublikasikan sebagai suatu pengumuman, dan event study digunakan untuk menguji kandungan informasi dari suatu pengumuman".

\section{Jenis dan Sumber Data}

Jenis data yang digunakan dalam penelitian ini adalah data sekunder yang meliputi:

a. Daftar perusahaan go public yang melakukan stock split dan tanggal pengumuman stock split dari tahun 2016 sampai dengan tahun 2018 yang diperoleh dari Indonesian stock exchange melalui galeri investasi Universitas Kadiri

b. Harga saham setiap hari dengan menggunakan ketentuan waktu 7 hari sebelum pengumuman stock split dan 7 hari sesudah pengumuman stock split

c. Abnormal return dengan menggunakan ketentuan waktu 7 hari sebelum pengumuman stock split dan 7 hari sesudah pengumuman stock split

d. Risiko sistematik saham yang dihitung dengan menggunakan ketentuan waktu 7 hari sebelum pengumuman stock split dan 7 hari sesudah pengumuman stock split

e. Adanya ketentuan waktu (perioede jendela) digunakan oleh peneliti untuk menghindari factor yang menjadikan hasil penelitian bias.

Sumber data dari penelitian ini adalah data sekunder, yang terdapat di Galeri Investasi Universitas Kadiri, Indonesian Capital Market Directory (ICMD) dan KSEI

\section{Populasi dan Sampel}

Data yang digunakan peneliti selama periode penelitian, terdapat 82 perusahaan dengan jumlah peristiwa stock split sebanyak satu kali peristiwa, kemudian peneliti mencari harga saham, abnormal return dan risiko sistematik saham dari masing-masing peristiwa stock split selama periode penelitian. 
Tabel 1 : Klasifikasi Perusahaan yang Melakukan Stock Split

\begin{tabular}{|c|c|c|c|}
\hline No & Tahun & Perusahaan yang terdaftar di BEI & Perusahaan yang melakukan stock split \\
\hline 1 & 2016 & 539 & 25 \\
\hline 2 & 2017 & 555 & 28 \\
\hline 3 & 2018 & 625 & 29 \\
\hline \multicolumn{2}{|c|}{} & total \\
\hline
\end{tabular}

Sumber : http://www.idx.co.id

\section{Variabel Penelitian}

1. Variabel Dependen (Y)

Variabel dependen dalam penelitian ini ada satu yaitu stock split yng dilakukan perusahaan yang terdaftar di BEI dalam periode 2016-2018. Halim (2015) mengatakan stock split adalah memecah jumlah lembar saham menjadi jumlah lembar yang lebih banyak dengan menggunakan nilai nominal yang lebih rendah per lembarnya secara proporsional. Tujuan dilakukannya stock split adalah untuk menjaga harga pasar saham agar tidak terlalu tinggi sehingga sahamnya lebih memasyarakat dan lebih banyak diperdagangkan.

2. Variabel Independen (X)

Variable indipenden dalam penelitian ini terdiri dari:

a. Harga Saham

Harga saham adalah harga suatu saham yang terjadi di pasar bursa pada saat tertentuyang ditentukan oleh pelaku pasar dan ditentukan oleh permintaan dan penawaran saham yang bersangkutan di pasar modal (Jogiyanto, 2008). Untuk mengukur harga saham digunakan harga saham penutupan pada periode pengamatan.

b. Abnormal Return

Abnormal return adalah selisih antara return sesungguhnya (actual return) yang terjadi dengan return ekspektasi (expected return). Formulasinya adalah, sebagai berikut (Jogiyanto, 2010):

$$
A R i, t=R i, t-E[R i, t]
$$

Keterangan:

ARi,t : Abnormal return sekuritas ke-i pada periode peristiwa ke-t. 
Ri,t : Return sesungguhnya yang terjadi untuk sekuritas ke-i pada periode peristiwa ke-t.

E [Ri,t]: Return ekspektasi sekuritas ke-i untuk periode peristiwa ke-t.

c. Risiko Sistematik

Risiko Sistematik merupakan resiko pasar yang dapat diwakili oleh nilai Beta. Beta merupakan koefisien pergerakan harga saham terhadap harga pasar. Beta adalah tolak ukur resiko dari suatu jenis saham dibandingkan dengan resiko pasar (Samsul, 2016). Secara matematis menurut Tandelilin (2010) Beta dapat dirumuskan dengan menggunakan metode indeks tunggal sebagai berikut:

$$
\begin{array}{r}
\mathrm{Y}=\beta 0+\beta 1+\varepsilon \\
\beta_{1}=\frac{\sum \mathrm{XY}-\mathrm{nXY}}{\sum \mathrm{XY}^{2}-\mathrm{nX}^{2}} \\
\beta_{0}-\mathrm{Y}-\mathrm{b}_{1} \mathrm{X}
\end{array}
$$

Keterangan:

$\mathrm{Y}=$ Return individual

$\mathrm{X}=$ Return indeks harga saham gabungan (IHSG)

$\mathrm{N}=$ Jumlah Data

$\beta=$ Beta

\section{HASIL \& PEMBAHASAN}

\section{Uji Hipotesis Variabel Harga Pasar Saham}

Dari hasil penelitian Hipotesis variable ini menunjukkan tidak ada perbedaan harga saham yang signifikan sebelum dan sesudah stock split. Dengan tingkat signifikansi yang digunakan 5\%. Dengan demikian dapat disimpulkan nilai signifikansi hasil Uji bernilai 0,04 lebih kecil dari tingkat signifikansi atau $\alpha(0,05)$, maka dapat disimpulkan bahwa HA diterima yang menunjukkan bahwa terdapat perbedaan harga saham sebelum dilakukan stock split dan sesudah dilakukan stock split. Hasil penelitian ini menunjukkan bahwa ada efek signaling theory yang menyatakan bahwa pengumuman stock split dianggap sebagai sinyal positif bagi perusahaan (hartono,2014). Sejalan dengan pernyataan (taendelilin,2015) yang menyatakan bahwa peristiwa stock split dapat meningkatkan harga saham karena peristiwa stock split menunjukkan sinyal optimisme 
dari manajemen perusahaan kedepannya. Pemegang saham dapat menangkap sinyal positif mengenai kinerja perusahaan. Hasil penelitian ini sesuai dengan Trading Range Theory yang menyatakan bahwa stock split dilakukan karena ada motivasi dari praktisi yang beranggapan bahwa harga saham memiliki nilai yang optimal.

Teori Likuiditas menyatakan bahwa stock split akan menyebabkan harga saham menjadi lebih terjangkau dan menarik bagi investor, sehingga saham menjadi lebih likuid. Saham yang lebih mudah diperjualbelikan di pasar modal dan melalui mekanisme pasar akan menyebabkan harga saham menjadi meningkat. Sama halnya dengan penelitian ini yang memberikan hasil bahwa rata-rata harga pasar saham relatif sebelum dan sesudah stock split menunjukkan peningkatan. Penelitian ini menunjukkan bahwa dengan adanya pengumuman peristiwa stock split, ada peningkatan harga saham sebesar 52,3\% . Hasil penelitian ini sesuai dengen penelitian Prasetyo (2016) yang menyatakan ada perbedaan harga saham sebelum dan sesudah peristiwa stock split.

\section{Uji hipotesis variable abnormal return}

\section{Tabel 2 Penelitian pada Tujuh Hari Sebelum Stock split dan Tujuh Hari Sesudah}

\section{Stock split.}

\begin{tabular}{|l|l|l|l|}
\hline $\begin{array}{l}\text { Periode } \\
\text { pengamatan }\end{array}$ & $\begin{array}{l}\text { Rata-rata } \\
\text { return saham }\end{array}$ & Return pasar & $\begin{array}{l}\text { Rata-rata abnormal } \\
\text { return }\end{array}$ \\
\hline T-7 & 0,02 & $-0,0015$ & 0,011 \\
\hline T-6 & 0,0028 & 0,0027 & 0,001 \\
\hline T-5 & 0,0045 & $-0,000345$ & 0,006 \\
\hline T-4 & 0,00846 & $-0,0045$ & 0,012 \\
\hline T-3 & $-0,0009$ & $-0,0067$ & 0,0075 \\
\hline T-2 & 0,027568 & 0,004851 & 0,016 \\
\hline $\mathrm{T}-1$ & 0,005705 & 0,002896 & 0,003 \\
\hline $\mathrm{T}$ & $-0,709391$ & 0,004967 & $-0,714$ \\
\hline $\mathrm{T}+1$ & $-0,006620$ & $-0,000282$ & $-0,008$ \\
\hline $\mathrm{T}+2$ & $-0,00560$ & 0,00208 & $-0,006$ \\
\hline $\mathrm{T}+3$ & $-0,004187$ & 0,000111 & $-0,004$ \\
\hline $\mathrm{T}+4$ & $-0,003102$ & $-0,00024$ & $-0,006$ \\
\hline $\mathrm{T}+5$ & $-0,004981$ & $-0,00006$ & $-0,004$ \\
\hline $\mathrm{T}+6$ & $-0,000761$ & 0,005159 & $-0,006$ \\
\hline $\mathrm{T}+7$ & $-0,000272$ & 0,00691 & $-0,007$ \\
\hline
\end{tabular}

Sumber: data diolah

Tabel diatas menunjukkan data yang dibagi $h-7$ sebelum peristiwa dan $h+7$ sesudah perdagangan saham. Rata-rata return saham pada T-7 sampai T-4 bernilai positif namun 
cenderung menurun. Hari ketiga menjelang stock split (T-3) return saham bernilai negative yang menunjukkan harga semakin menurun. Hal ini menunjukkan alasan perusahaan-perusahaan melakukan stock split.

Return saham mengalami penurunan pada saat terjadi stock split, hal ini disebabkan dengan adanya stock split yaitu satu lembar saham dipecah menjadi beberapa lembar saham yang membuat nilai nominal saham juga mengecil dimana diikuti dengan turunnya harga lembar saham.

Saat harga saham turun maka return akan bernilai negatif dan selisih dengan return saham sehari sebelum stock split sangat jauh. Enam hari setelah stock split return masih bernilai negatif namun menunjukkan peningkatan. Kondisi ini karena investor masih memiliki keragu-raguan untuk menanamkan modal pada perusahaan yang melakukan stock split. Mereka lebih memilih menunggu return berubah menjadi positif karena sebagian besar investor tidak ingin mengalami kerugian. Peristiwa stock split memberikan pengaruh pada reaksi pasar dengan adanya abnormal return yang memberikan adanya informasi. Abnormal return positif menunjukkan adanya peristiwa berita yang baik, sedangkan abnormal return yang bernilai negative menunjukkan suatu peritiwa membawa berita buruk.

Dari data statistic yang diolah menunjukkan abnormal return sebesar 0,002 dan lebih kecil dari nilai $\alpha(0,05)$. hal ini menunjukkan bahwa peristiwa stock split membuat abnormal return yang berbeda sebelum terjadi stock split dan sesudah stock split. Investor cenderung menunggu abnormal return beranjak ke nilai positif terlebih dahulu supaya invetasinya mendapatkan return yang maksimal. Sebagian besar investor yang tidak naif mengetahui bahwa perusahaan yang melakukan stock split akan membutuhkan biaya yang banyak untuk melakukan kegiatan stock split sehingga mereka beranggapan bahwa stock split tidak menaikkan return yang akan diperolehnya bahkan bisa menurunkan return yang akan diperolehnya. Hal ini sejalan dengan pendapat taendelilin (2013) yang menyatakan satu kerugian dilakukannya stock split bagi perusahaan adalah adanya biaya pemecahan yang termasuk didalamnya biaya transfer agen untuk proses sertifikat dan biaya lainnya.

Hasil penelitian ini berlawanan dengan signalling theory karena investor dapat memprediksi informasi yang dibawa oleh adanya peristiwa stock split dan lebih mempercayai perusahaan-perusahaan yang benar-benar memberikan return atau keuntungan daripada perusahaan yang hanya menjanjikan keuntungan di masa yang akan datang. 


\section{Uji hipotesis variabel risiko sistematik}

Berdasarkan hasil analisis dari pengujian secara statistik, maka diperoleh hasil bahwa Risiko Sistematik tidak memiliki pengaruh signifikan terhadap harga saham. Hal ini mengindikasikan bahwa faktor internal perusahaan tidak terpengaruh dengan peristiwa stock split, sedangkan faktor eksternal perusahaan seperti kondisi perekonomian yang meliputi: inflasi, GNP, GDP, mempunyai pengaruh terhadap risiko sistematik. Selain itu hasil penelitian ini juga menunjukkan bahwa tidak terdapat kandungan informasi dari pengumuman stock split yang dibuktikan dengan tidak bereaksi nya pasar terhadap informasi pengumuman stock split. Tidak terdapatnya perbedaan risiko sistematik yang signifikan memberikan informasi kepada investor bahwa volatilitas dari saham emiten tersebut mengikuti fluktuasi dari return pasar jika beta bergerak menuju 1, apabila lebih dari 1 maka melebihi fluktuasi dari return pasar, dan jika kurang dari 1 maka menjauhi fluktuasi dari return pasar. Investor yang menyukai risiko akan membeli saham yang berfluktuasi melebihi return pasar, sedangkan investor yang tidak menyukai risiko akan membeli saham yang berfluktuasi menjauhi return pasar, sehingga akan berdampak pada kenaikan likuiditas perusahaan.

Tidak berpengaruhnya risiko sistematik (beta) terhadap saham mengindikasikan bahwa ketidakstabilan pasar menyebabkan sebagian besar investor membeli saham untuk tujuan laba jangka pendek berupa capital gain sehingga risiko sistematik ( $\beta$ ) yang terjadi di pasar tidak berpengaruh terhadap saham

\section{SIMPULAN \& SARAN}

\section{Simpulan}

Berdasarkan hasil analisis yang berkaitan dengan tujuan penelitian ini, maka dapat di tarik beberapa kesimpulan hasil penelitian sebagai berikut:

1. Terdapat perbedaan harga saham sebelum dan sesudah peristiwa stock split, hal ini ditunjukkan dengan nilai signifikansi 0,004 lebih kecil dari nilai $\alpha(0,05)$ selama periode pengamatan

2. Terdapat perbedaan abnormal return sebelum dan sesudah stock split. Hal ini terlihat dari hasil analisis selama periode pengamatan yang menunjukkan nilai signfikansi 0,002 lebih kecil dari $\alpha(0,05)$ yang berarti ada perbedaan abnormal return antara tujuh hari sebelum dan tujuh hari sesudah 
stock split. Alasan yang mendasari hal tersebut adalah tanggapan pasar yang kurang baik terhadap kegiatan stock split yang dilakukan oleh emiten.

3. Risiko sistematik tidak menunjukkan perbedaan setelah dan sebelum adanya peristiwa stock split, hal ini dikarenakan kondisi internal perusahaan selain itu Tidak berpengaruhnya risiko sistematik (beta) terhadap saham mengindikasikan bahwa ketidakstabilan pasar menyebabkan sebagian besar investor membeli saham untuk tujuan laba jangka pendek berupa capital gain sehingga risiko sistematik ( $\beta$ ) yang terjadi di pasar tidak berpengaruh terhadap saham

\section{Saran}

1. Bagi investor, informasi yang terjadi di pasar modal tidak semua merupakan informasi yang berharga, karena itu pelaku pasar modal harus secara tepat memilah dan menganalisis informasi-informasi yang relevan untuk dijadikan pertimbangan dalam pengambilan keputusan, sehingga diharapkan investor tidak terburu-buru untuk melakukan aksi jual beli dan lebih bersikap rasional dalam pengambilan keputusan.

2. Hasil penelitian memberikan masukan bagi emiten bahwa aktifitas stock split tidak menjanjikan bahwa abnormal return juga akan meningkat sesuai dengan tujuannya. Oleh karena itu, emiten hendaknya jangan terlalu memfokuskan pada peristiwa stock split saja, namun terfokus kepada cara agar kinerja perusahaan dapat meningkat setelah adanya keputusan stock split, sehingga kepercayaan investor akan semakin meningkat kepada emiten.

3. Penelitian berikutnya disarankan untuk menguji variable lain yang dapat memberikan pengaruh dengan adanya peristiwa stock split dengan rentang waktu pengamatan yang lebih panjang sehingga lebih mencerminkan kondisi pasar

\section{DAFTAR PUSTAKA}

Alteza, Muniya, dkk. (2014). Perubahan Likuiditas Akibat Stock split: Studi di Pasar Modal Indonesia. Jurnal Economia, Volume10, Nomor1. Yogyakarta: Universitas Negeri Yogyakarta.

Ang, Robert. 2007. Buku pintar Pasar modal Indonesia. Jakarta : Mediasoft Indonesia.

Anomsari, Fitri. 2007. Analisis Reaksi Pasar Terhadap Peristiwa Stock Split Perusahaan Yang Go Publik di Bursa Efek Jakarta. Volume 11,Nomor 4.

Brigham, E.F. dan Houston. (2010). Dasar-dasar Manajemen Keuangan. Edisi 11. Buku 1. Jakarta: Salemba Empat. 
Brigham, E.F. dan Houston. (2011). Dasar-dasar Manajemen Keuangan. Edisi 11. Buku 2. Jakarta: Salemba Empat.

Brennan, J. Michael dan Thomas E. Copeland. 1988. "Stock Splits, Stok Prices, and Transaction Cost". Dalam Journal of financial Economics Vol 22 83101

Bodie, et al. Investasi. Salemba empat. Jakarta. 2006

Bodie, Kane,Marcus.2008 "Investasi” Buku 1 Edisi 6. Salemba Empat : Jakarta

Conroy,R.M,R.S, Harris dan B.A. Benet. (1990). The Effect of Stock Splits on Bid-Ask Spread. Journal of Finance 4.Corporate Finance. New York:

Darmadji, Tjiptono. dan Fakhruddin, Hendy M. (2001). Pasar Modal di Indonesia. Pendekatan Tanya Jawab. Jakarta: SalembaEmpat.

Djajasaputra. (2012). Perbandingan Harga Saham, Volume Perdagangan Saham, dan Abnormal Return Saham Sebelum dan Sesudah Stock split. Jurnal Riset Akuntansi Indonesia, Vol.2, No.1P.

Damayanti, Ni Luh. Anantawikrama, dan Nyoman. (2014). Analisis Pengaruh Stock split (Stock Split) Terhadap Tingkat Keuntungan (Return) Saham dan Likuiditas Saham. e-Journal S1 Akuntansi Universitas Pendidikan Ganesha.

Gautama, Udhi Pamungkas. (2008). Pengaruh Stock Split Terhadap Future Profitability, Likuiditas Saham, dan Struktur Kepemilikan pada Perusahaan yang Terdaftar di Bursa Efek Indonesia. Tesis diterbitkan. Yogyakarta: Universitas Gadjah Mada.

Ghozali, Imam. (2006). Aplikasi Analisis Multivariate dengan Program SPSS. Semarang: Badan Penerbit Universitas Diponegoro.

Horne,Van James C,dan John M Wachowicz. 2007. Prinsip-prinsip Manajemen Keuangan. Buku 2. Salemba 4.Jakarta.

Hadi, Nor. (2013). Pasar Modal "Acuan Teoritis dan Praktis Investasi dan Instrumen K euangan Modal" . Yogyakarta: Graha Ilmu.

Halim, Abdul. (2005). Analisis Investasi. Edisi 2. Jakarta: Salemba Empat.

Hansen, Don. R. dan M. Mowen, Mayane. (2001). Manajemen Biasa Akuntansi dan Pengendalian. Buku Dua. Edisi Kesatu. Jakarta: Salemba Empat.

Harahap, Sofyan. (2001). Sistem Pengawasan Manajemen. Jakarta: Quantum.

Hartono, Jogiyanto. (2008). Teori Portofolio dan Analisis Investasi. Edisi Kelima. Yogyakarta: BPFE.

Ika W, Anuragabudhi dan Anna Purwaningsih. 2008. Reaksi Pasar Terhadap Pengumuman Stock Split:Studi Empiris pada Perusahaan Manufaktur yang Terdaftar di Bursa Efek Jakarta.Telaah Manajemen.Vol 3, No 1.

Jogiyanto, Hartono. 2013. Teori Portofolio dan Analisis Investasi. BPFE Yogyakarta. Edisi Kelima. Yogyakarta.

Permadi. (2013). Pengaruh Stock Split Terhadap Return Saham, Future Profitability, dan Likuiditas Perdagangan saham. Tesis. Yogyakarta: Universitas Gadjah Mada.

Rusdin. (2008). Pasar Modal: Teori, Masalah, dan Kebijakan dalam Praktik. Bandung: Alfabeta.

Tandelilin, Eduardus. 2011. Analisis investasi dan Manajemen Portofolio. Yogyakarta : BPFE.

Putra, Y. P., \& Yuliari, K. (2017). Analisis Unit Cost Mahasiswa Berdasarkan Activity Based Costing (ABC) Pada Fakultas Ekonomi Universitas "X" Di Kota Kediri. NUSAMBA, 2(1), 47-56. https://doi.org/https://doi.org/10.29407/nusamba.v2i1.563 